\title{
Sibling tension and negotiation Malay(sian) writer-political activists' links and orientation to Indonesia
}

\section{Budiawan}

We might see the cultural traffic between Indonesia and abroad in 1950-1965 as an imbalanced flow of influences, in which Indonesia was in the position of being influenced rather than the reverse. While Indonesian cultural workers presented their works abroad, searched for inspiration from and extended their references to various sites of 'world' cultures, as other contributors to this volume discuss, subsequently they processed imported ideas into 'local' expressions, to fit the aspiration for so-called national identity. ${ }^{1}$ This was common in recently decolonized nations, since the 'nation building project' was at the initial stage.

The case of Indonesia-Malaya cultural traffic, particularly in literature, however, tends to show the opposite direction. Rather than being the importer, Indonesia was the exporter of literary works and ideas to Malaya without, to a great extent, necessarily being aware of it, for it was the latter that took initiatives to search for inspiration from the former. In short, Indonesia became the 'Mecca' for the writers of Malaya, ${ }^{2}$ especially the Malay writers, both in the given period and even earlier. ${ }^{3}$

1 Yet, as the idea of 'national identity' was (and is) contested, the creative processes of adapting to 'local' expressions tended to run in hot and even endless debates. Keith Foulcher's chapter in this volume is the study of such a cultural debate in post-independence Indonesia. 2 Until the breakdown of the Malaysian Federation in 1965, after which Malaysia and Singapore were separated, the term 'Malaya' referred to the whole British colonies of the peninsula including the island of Singapore.

3 Such a direction of influences however, did not happen in popular culture. In theatre and film, for instance, instead of importing from Indonesia, Malaya was exporting its works to Indonesia. The popularity of Malayan bangsawan performers such as Habsah binte Buang, for instance, reached beyond Singapore and the peninsula. Performances of this theatre group in big cities of Sumatra, Java and Kalimantan were common; while films produced by Shaw Brothers' Malay Film Productions and Cathay Keris were very popular in Indonesia. On a short study of Malay films and theatres from 1940s to 1965, see Barnard 2009. 
This historical fact is not something new to Malay(sian) scholars and cultural workers. Despite the more 'inward-looking nationalistic' tone in their creative processes over the last two decades, Malay(sian) cultural workers acknowledge their past cultural debts to Indonesia, particularly in the colonial era and until the 1970s. Their sense of having shared 'cultural roots' within the idea of 'bangsa serumpun' is well-maintained, as is seen in the formation of various regional cultural networks and associations.

On the other hand, only a few Indonesians have learned this fact well; and few have noticed how Malay writers imported and processed borrowed ideas from Indonesia into their own expressions. Consequently, while the creations of Malay(sian) writers may have resonance with Indonesian works, these are unfamiliar to most Indonesians. We might ask how many Indonesians read Malay(sian) literary works, whereas almost every Malay(sian) secondary school student reads Indonesian literary works. ${ }^{4}$ Indonesian scholar Maman S. Mahayana even claims that 'Malaysian literature is like a foreign literature to the Indonesians, more foreign than English, Dutch, or Japanese, Chinese and Indian literatures' ${ }^{5}$ On the other hand, Indonesian literature is by no means unfamiliar to Malaysians (Maman S. Mahayana 2001:ix), since it has long been considered part of their literature. ${ }^{6}$

Perhaps Maman is a little exaggerating. However, coming from such a concern this paper aims to explore the historical processes of Malaya - Indonesia literary links in 1950-1965. The focus is on how Malay writers, most of whom were political activists and journalists as well, sought inspiration from Indonesia in their creative processes as a part of the struggle for the Malayan independence. As a preliminary study, this paper is limited to showing the links the Malay writers built with Indonesia, and how these links affected and were affected by the political relations between the two countries.

4 The poems of Amir Hamzah, for instance, were used as the main reading materials in the module of Nusantara Literature in secondary schools in Malaya in the1960s, and have been used as compulsory texts for the final exams since 2000. In addition, the works of other prominent Indonesian writers including Pramoedya Ananta Toer, Sitor Situmorang and Chairil Anwar, were read extensively by secondary school students in Malaysia. See Shafwan Hadi Umry 2008; while in Indonesia, very few secondary school students read Malaysian literary works, and it is only at the Universitas Sumatera Utara (Medan), there is a module on comparative literature of Indonesia and Malaysia. See Mula Harahap n.d.

5 In original text: kesusasteraan Malaysia bagi kita di Indonesia laksana kesusasteraan asing yang lebih asing dari kesusasteraan Inggris, Belanda, atau Jepang, Cina dan India.

6 Jassin 1983:5. Even Jassin (1983:5) adds that many Indonesian literary works no longer available in the market in Indonesia were reprinted in Malaysia. This was his observation in the early 1980 s, when the economic development and political stability dominated the public discourse, marginalizing the concern for culture, especially literature. 
I am limiting my discussion to literary writers because, as I will demonstrate later, in the context of Malaya-Indonesia cultural links and traffic, they were the primary agents of the ways that political ideas were initially transmitted, and at a crucial time they played a part in resolving the political tension between the two countries. This is thus a good example of ways that literature (as the text of ideas) and politics (as the action of the texts) are closely intertwined.

The focus of my discussion is elaborated into questions as follows: how were the modern Indonesian-Malayan cultural (especially literary) networks built? Who took the initiatives of building the networks? What was the frequency of travel of writers of both countries? Who travelled where, and what did they do in their neighbour country? What had made such a network possible? How were these networks affected by, and how did they affect, the political dynamics in each country?

In addressing these questions, I will first discuss the historical development prior to 1950. As many historical accounts of the Malayan political movement note, the nationalist struggles of Malays to independence was much affected by their Indonesian nationalist counterparts in the 1930s, or even earlier. ${ }^{7}$ As literary activism was inseparable from political activism, the course of political history seemed to be not only in parallel but also closely linked to the course of literary history.

Secondly, I will discuss the historical development from 1950 to 1957 . This was a crucial period in Malayan history, as the British colonial rulers imposed the state of emergency, by which political activism was tightly controlled. In such conditions, literary activism increased among Malay activists, as indicated by the formation of the 'Angkatan Sasterawan 50' (Generation of the Writers of 1950, or ASAS 50). I will describe the links of ASAS 50 to Indonesian literary activism until 1957, when the Federation of Malaya attained its independence from the British. It is interesting to examine how 'Malay' sentiment was articulated, when 'Malayness' began to have some political meaning, by which the 'politics of difference' was inevitable.

Thirdly, I will discuss the 'exchange' of Malayn and Indonesian writer-activists from the attainment of Malayan independence (1957) until the outbreak of 'Confrontation' (1963). I will examine to what extent such cultural links and networks were affected by the political tensions and dispute between the two countries.

7 This is not meant to imply that non-Malays, in extenso the Chinese and the Indians, were not involved in the struggle for the Malayan independence. However, since the focus of discussion is Malay writers, particularly the leftist Malays, this essay does not discuss the roles of the Chinese and the Indians in the struggle for the Malayan independence. 
EARLY CONTACTS OF MODERN MALAY ACTIVISTS WITH INDONESIA; $193^{\circ}-195^{\circ}$

Malaysian scholar Ahmad Kamal Abdullah notes that the growth and development of modern Malaysian literature and Indonesian literature were inseparable. The early stage was visible in the 1930s, when young Malay writers such as Harun Aminurrasyid, Muhammad Yasin Makmur, and Abdullah Sidek were intensively engaged with the works of the Pujangga Baru writers. ${ }^{8}$ However, as William R. Roff remarks, the seeds of contact were in fact laid down earlier. Around the mid-1920s, many students of Sultan Idris Training College (SITC) - established in 1913 in Taiping but later moved to Tanjung Malim, Perak, in 1922 - already enjoyed Balai Pustaka's novels and other modern literature bought for the college library. Individual teachers and students also subscribed to Indonesian periodicals, ${ }^{9}$ which they read in conjunction with the new Malay newspapers and journals also coming out at about this time (Roff 1967:155).

As an educational institution to train teachers for the Malay schools, the SITC was the primary site from which Indonesian influences were spread throughout the Peninsula. This, as Hooker describes, was because 'its graduates believed that Malays were not keeping up with the changes of the modern world and needed to work hard to catch up with the progress they believed was happening around them. In touch with anti-colonial and nationalist student movements in Indonesia, they went out into their communities determined to inspire change through teaching and writings' (Hooker 2003:172).

The 'fascination' of Indonesian literary activism to the Malay intelligentsia was in fact by then already something common. Ishak bin Haji Mohd., for instance, in the 1930s became increasingly interested in the cultural, and especially literary renaissance manifest in the Indonesian peoples in the Netherlands Indies. He read all the Indonesian books and periodicals he could lay his hands on (Roff 1967:228).

The promotion of Indonesia as the source of inspiration for change and progress was also taught at schools. By exposing Indonesian nationalist activism, the teachers at the SITC inspired a number of students, led by Ibrahim Yaakub, to form Belia Malaya (Young Malaya) in early 1930. This organization was modelled on similar youth groups

8 Ahmad Kamal Abdullah 2006:68. See also the short version of this article under the author's pseudonym Kemala (n.d.).

9 One of the Indonesian periodicals they subscribed to was Fikiran Rakjat, in which political activists such as Soekarno frequently wrote articles expressing the ideas of anti-imperialism, anti-colonialism and anti-feudalism, and articulated nationalist thoughts and national independence. On the fact that they subscribed to Fikiran Rakjat, see Roff (1967:173, footnote 121, 225). 
in Java and Sumatra, dedicated to the unification and joint advancement of the Malay and Indonesian languages (Roff 1967:225).

Despite its short life, Belia Malaya was likely an embryo for the formation of the first political organization among the Malays, namely the Kesatuan Melayu Muda (KMM, Union of Malay Youth) in $1938 .{ }^{10}$ As told by Mustapha Hussain, one of the KMM's founders, Ibrahim once admitted that he had been intensely influenced by Indonesian political movements. History lessons delivered by teachers inspired him; and with three friends he secretly enrolled in the Soekarno-led Partai Nasional Indonesia (PNI, Indonesian National Party) in 1929. ${ }^{11}$ Unsurprisingly from that beginning, Ibrahim Yaakub had an ambition of struggling for Malayan Independence as part of Indonesian Independence under the idea of 'Indonesia Raya' (Greater Indonesia). ${ }^{12}$

However, not all of the Indonesian-influenced Malay intelligentsia shared this nationalist aspiration. Mustapha Hussain, for instance, was close to a number of Indonesian nationalists, yet he never subscribed to the idea of the struggle for Malayan Independence as a part of Indonesia.

Despite the different nationalist aspirations among the Malays, the most important thing to note in their initial contacts with the Indonesian nationalists was that the term 'politics' began to enter into the public discourse among them. This invention of 'politics' was something phenomenal in the pre-war Malayan history. As Anthony Milner notes, certain Malay writers have even remarked that until the late colonial period, 'no politics' existed among the Malays. Milner suspects that this comment refers to the absence of more than just political institutions and political parties. There was in the Malay language no specific word for 'politics'. ${ }^{13}$

10 The other founders of KMM included Mustapha Hussain, Hassan Haji Manan, Othman Mohd. Noor, Idris Hakim, Abdul Karim Rashid. Many were either school teachers or journalists, and some were government clerks. On the working committee of KMM and the life story of each member, see Mustapha Hussain 2005:135-61.

11 Mustapha Hussain 2005:145. The three friends joining Soekarno's PNI were Hassan Manan, Abdul Karim Rashid, and Isa Mohd. bin Mahmud. As PNI members they subscribed to Fikiran Rakjat, the organ of the party. See Roff 1967:225.

12 Soh 2005. Yet, this idea failed to get enough support among the Malays. He even fled to Indonesia, just after the Japanese surrendered to the Allied Forces and before the British troops returned to Malaya in September 1945. Ibrahim later became an Indonesian citizen and changed his name to Iskandar Kamil. He then ran a banking business. When he passed away in 1979, he was honoured by the Indonesian government with burial in the Heroes' Cemetery in Kalibata, Jakarta. On the life story of Ibrahim Yaakub told from the perspective of a former alliance betrayed, see Mustapha Hussain 2005.

13 Milner 2002:2. The terms 'politik', and then 'merdeka'were indeed imported from Indonesian, as acknowledged by Malay communists such as Abdullah C.D. See Islam, Melayu, komunis 2005:15. 
How 'politics' then shaped the consciousness of being a collective entity among the Malays was crucially visible in their rejection of the British colonial rulers' proposal of Malayan Union in 1946. It was a proposal consisting of three points: the sovereignty of the rulers would be transferred to the British Crown, the autonomy of individual Malay states would be absorbed into the Union, and the privileges which had previously been reserved for the Malays would be available to members of other communities (Hooker 2003:187).

To the Malays, this proposal did not promise independence, and it gave much concession to the non-Malays. Whereas by this time they were witnessing the tide of anti-colonial mood in other parts of Asia, such as Indonesia, Indo-China, and India. Even among the radical Malay nationalist fighters, as one of its veterans Said Zahari notes, Indonesia was seen as 'the centre of political power, capable of pioneering the national struggle for freedom of the entire archipelago from western domination'. ${ }^{14}$

Malay popular reaction against the Malayan Union was the causal factor that provided the catalyst to Malay nationalism. The Malay elites believed that a political system offering a common citizenship and equal political rights for all would destroy the Malay race. The Malay congresses held in 1946 led to the formation of the United Malays National Organization (UMNO), which became the primary organization for protecting and promoting the Malay interests. The conservative, English-speaking traditional leaders, formerly supportive of British rule, now led the struggle against the Malayan Union and emerged as the undisputed leaders of Malay society as a whole (Mauzy 2006:49).

Consequently, the radical and Leftist Malay nationalists initiating the nationalist movement in the 1930s were marginalized. They lost their momentum to enhance their own aspirations when the British agreed to abrogate the Malayan Union and invited UMNO to draft a plan for a more suitable constitutional arrangement. In addition, British repressive measures against the Leftists as a counter to the communist insurgency in late 1940s led to the Leftists being expelled from the Peninsula. Many moved to Singapore.

However, as Joel S. Kahn notes, the British crackdown on overt political activities and organizations soon spread from the Peninsula

14 Said Zahari 2007:5. It is noteworthy that the British proposal of Malayan Union was in fact a counter to the idea of Malayan Independence as a part of Indonesia as proposed by Kesatuan Rakyat Indonesia Semenanjung (KRIS, Union of Peninsular Indonesians, later changed to Kekuatan Rakyat IStimewa, Special Strength of the People). A similar change of name attached to a known acronym happened to KMM, which was previously Kesatuan Melayu Muda (Union of Malay Youth) and changed to Kesatuan Melayu Merdeka (Union of Malay Independence), indicating the shift to the aspiration for a form of popular nationalism). 
to Singapore itself. The result was that they turned away from overt forms of political activity. This generated, in turn, a renaissance of Malay literature and the arts. In the 1950s, Singapore became the centre of an often highly politicized Malay artistic and literary scene. ${ }^{15}$ One of the noteworthy cultural events was the formation of Angkatan Sasterawan 50 (the Association of the 1950 Writers, or better known as ASAS 50). I will now discuss the formation of this association and its links to Indonesia until the Federation of Malaya gained its independence in 1957, a moment when 'Malayness' in a political sense began to be defined more intensely and become placed in legal framework.

\section{THE FORMATION OF ASAS 50: ITS DYNAMICS AND LINKS TO} INDONESIA UNTIL 1957

Founded after a meeting on 6 August 1950 at the home of a graduate of the SITC, Mohd. Ariff Ahmad, ASAS 50 was the first literary association in post-war Malaya. It was an association representing the voice of the community, which utilized literature as the ideal thrust towards independence for Malaya. Its manifesto of 'Sastra untuk Masyarakat' (Literature for Society) together with its pioneers such as Asraf, Keris Mas, Tongkat Warrant (or Usman Awang), Masuri SN and Awani Sarkam, ${ }^{16}$ formed the main shaping force in the development of modern Malay literature. ${ }^{17}$

According to one of its founders, Masuri S.N., as cited by Maman, the name 'ASAS 50' initially emerged when Sutan Takdir Alisjahbana (STA) met with a number of Malay writers in Singapore prior to the formation of this association. When STA asked

15 Kahn 2006:114. In film production, for instance, as Barnard (2009:127) notes, in the twenty-year period following World War Two, Singapore witnessed the 'Golden Age'. During this period, over 200 films were produced.

16 Kahn 2006:115. In the website of ASAS 50, the list of the founders of this association is written as follows (most of them with their pen names in brackets): Muhammad Ariff Ahmad (MAS), Kamaluddin Muhammad (Keris Mas), Abdul Wahab Muhammad (Awamil Sirkam), Abdul Jalil Haji Nor (Merayu Rawan), Munir Ali (Rosmera), Kumasi Haji Dainuri (Teruna Jaya), Abdul Majid Husain (Hamzah), Masuri Salikun (Masuri S.N.), Abu Yamin Kasun, Ahmad Ramli Abdul Karim (Ramlimah), Muhammad Daud and Muhammad Yusof Yaacob (Jim). See at http://www. asas50.com. Kahn mentions only some of the founders, while in the website of ASAS 50, Usman Awang, one of the most prominent Malay writers in the $1950 \mathrm{~s}$, is peculiarly not mentioned. The website does not provide enough information about the historical background of ASAS 50. It exposes the contributions to the recent development of the Malay(sian) arts and culture, demonstrating its relevance and significance to the present Malay(sian) literary condition.

17 See at http://www.asas50.com. 
one of the members about the name of this would-be association, the latter said that they were 'Sasterawan Angkatan 1950', following Indonesia's 'Angkatan 1945', ${ }^{18}$ as they were impressed by the Indonesian revolution and influenced by the works of the 'Angkatan 1945’ (Li Chuan Siu 1975:23).

The fact that even in naming their organization these writers followed the Indonesian model was no surprise, since most of them had belonged to the Malayan Nationalist Party. Reprising the wartime idea of a Greater Indonesia, this party still envisioned independent Malaya as a part of Indonesia. Therefore these writers kept looking at Indonesia as their primary reference, while many of them built personal links with their Indonesian counterparts. They read literary works of Indonesian writers, while the mass media they managed, such as the newsmagazine Persatuan, covered news from and about Indonesia (Maman S. Mahayana 2001:92).

The way that Indonesia was seen as 'Mecca' by the writers of ASAS 50 is, for instance, obvious in one column by a Malaysian columnist Rustam A. Sani. In his obituary of Usman Awang, one of the prominent activists of ASAS 50, Rustam writes that while the [aristocratic] Malay elites were hegemonized by the colonial education, those belonging to ASAS 50 were fascinated by the dynamics of Western arts and culture through modern Indonesian literature. Indonesian writers were experimenting with ideas and expression while enhancing the Malay language (having been officially named Bahasa Indonesia) by exploring broader references of ideas, including Western ones. Usman and his fellow Malay writers used the works of Indonesian writers as a sort of university, through which they modernized the Malay literature. ${ }^{19}$

18 Maman S. Mahayana 2001:208. The Indonesian literary critic Ajip Rosidi once wrote that the naming of 'Angkatan', which is the translation of Dutch word generatie (generation), by the writers claiming to belong the generation themselves was in fact ridiculous. Naming of a generation and its relation to categorizing literary history into periods should be the concern of literary critics, instead of the writers themselves. This is because 'periodization' should be based on genres, not on the age of its writers, or political phase. See a review of Ajip Rosidi's Masalah angkatan dan periodisasi sejarah sastra Indonesia (1973) by an anonymous reviewer at http://bukudanhanyabuku.blogspot.com/2008/02/masalah-angkatan-dan-periodisasi.html.

19 Rustam A. Sani n.d. As noted by Dato Dr Kemala (the pseudonym of Ahmad Kamal Abdullah), Usman Awang's works were much influenced by the works of Amir Hamzah, Sejarah Melayu and Hikayat Hang Tuah. In addition, he had close personal links with contemporary Indonesian poets such as W.S. Rendra, Taufiq Ismail, Goenawan Mohamad, Abdul Hadi W.M. and Leon Agusta. However, Kemala (2008) adds, to a great extent the 'Malayness' of Usman's works was distinct, and can only be understood by the Malaysian Malays. Yet, he does not elaborate in what ways those works 'can only be understood by the Malaysian Malays'. This is likely indicative of the rise of 'Malayness of Malaysia', in comparison to, perhaps, 'Malayness of Indonesia', into which the political meaning of 'Malayness' is inserted. On how 'Malayness' is contested in postindependence Malaysia, see Barnard 2004. 
Another example of a Malay writer-activist having personal links with Indonesians was A. Samad Ismail. As a part-time correspondent for Indonesia's Antara news agency, with its 'offices' at Utusan Melayu - where, in the spirit of solidarity, Samad and his cohorts called each other 'Bung' (as in Bung Samad and Bung Kamal) mimicking the fashion in revolutionary Indonesia - he came to know several Indonesian leaders, including Adam Malik, Sutan Sjahrir, Haji Agus Salim, and A. K. Ghani. ${ }^{20}$

Although Samad was not officially a member of ASAS 50, as the editor of Utusan Melayu he was the mentor for the members of this association (Rajakumar 1987:39), or the one who 'threw himself behind ASAS 50' (Kamaluddin Muhammad 1987:37). At Utusan Melayu and its affiliate publications, he drew around him some of the best Malay writers of the times, including Kamaluddin Muhammad and Usman Awang, filling the newspaper's pages with their stories, poems, and essays and contributing several of his own under various pen names. The ASAS 50 writers consciously fostered Malay nationalism and, at the same time, promoted writing in Malay as an act of national expression. Moreover, says Samad, 'they wrote about poor people, laborers, and peasants and the struggle against poverty, the inequities of landlordism' (Rush n.d.).

Obviously, the manifesto of ASAS 50 was much in parallel with that of Lembaga Kebudayaan Rakyat (LEKRA, the Institute of People's Culture) in Indonesia, in the sense that they shared the idea of 'engaged literature'. ${ }^{21}$ The term 'masyarakat' here did not only refer to race, that is the Malays as a whole, but particularly to class, that is the poor or the working class Malays. However, virtually no sources mention that members of ASAS 50 had close links with the members of LEKRA. ${ }^{22}$ Three explanations could be presented here. First, LEKRA itself was still then at the initial stage. Internally it still had to consolidate and to lay down the ideological foundation for its members, alongside the agenda of its patron, the Indonesian Communist Party (PKI) which was reviving after being crushed in the 'Madiun Affair' of 1948.

Second, from Malaya's side, despite the presence of radical elements on the Malay nationalist scene of post-war Singapore, it was ultimately the more conservative nationalist elements that

20 Rush n.d. Dato Dr Kemala (2008) mentions that Samad Ismail was also close to Mochtar Lubis.

21 My gratitude to Keith Foulcher for reminding me of this term.

22 In his study on the comparison of the literary systems and ideological conflicts in Indonesia and Malaysia, Maman S. Mahayana himself could only speculate that the polemic in Malaysia between those supporting 'arts for society' against those supporting the 'arts for the arts' might have been influenced by what was happening in Indonesia. See Maman S. Mahayana 2001:233. 
assumed control of the movement. The work of the 1950s Malay artists and literary figures, most of them associated with ASAS 50 , may now still be considered part of the Malay literary canon (as obviously seen in the works of Usman Awang as mentioned above). Their more radical, cosmopolitan brand of nationalism was effectively suppressed as a consequence of the rise of UMNO (Kahn 2006:115).

Third, as the consequence of the UMNO's dominance in the Malay nationalist movement, the issue of 'nationhood', which by then meant promoting the rights and privileges of the Malays in co-existence with the non-Malays, was more dominant, rather than the issue of 'kerakyatan' ('peoplehood') in the sense of class perspective, free of ethno-nationalism, promoted by the Malay (and non-Malay) Leftist nationalists. The cultural and political agenda promoting 'Malayness' was then dominating the nationalist discourse. One of the noteworthy outcomes of this sort of struggle in pre-independence Malaya was the introduction of the Roman spelling in the Malay language, as one of the important results of the Third Malay Language and Literary Congress initiated by ASAS 50 in $1956 .{ }^{23}$

Concerning the introduction of the Roman spelling (or 'Rumi' as the Malays call it) and the promotion of the Malay language, the general chairman of UMNO Tunku Abdul Rahman Putra Al-Haj repeatedly mentioned Indonesia as the model. In his speech over Radio Malaya on 30th June, 1956, he said:

During my visit to Indonesia I was taken around the universities and libraries. At the universities there are many graduates taking up various courses of studies. All the graduates are Indonesians, Chinese and Eurasians. But they all use Rumi. When our country achieves independence, a number of our children would like to take up higher studies. They may go to Indonesia and with the knowledge of Rumi script they can easily enter the Indonesian universities. In the libraries are books in Rumi which will be a great help to use here. But if we do not know Rumi, how can we read them? ${ }^{24}$

He repeated this point in his speech at the opening ceremony of the Third Malay Language and Literary Congress in Johore Bahru, 16 September 1956:

23 See http://www.asas50.com.

24 Tunku Abdul Rahman Putra Al-Haj 2007:97-8. Tunku Abdul Rahman was likely speaking in Malay. Yet, the book cited above is in English, so that his speech as cited above is already translated into English by the publisher. 
When I visited Indonesia last year I was greatly impressed by the efforts made to encourage the people to use the Malay language, which is called the Indonesian language there, with the result that within a short time it became the medium of instruction in the universities. So with Indonesia having made such an advance and carried out a research on the language the work of our language experts here will certainly be made easier, but we have to work hand in hand with the Indonesians. Any notion by our language experts here that we should ignore Indonesia and make our own planning will, I am afraid, make the Malay language to branch into two, three or four directions. ${ }^{25}$

Again he emphasized the importance of cooperation and collaboration between the Malay experts and their Indonesian counterparts, in his ambition of making the Malay language like the English language, in which 'the meaning of words are the same everywhere although the sound is different when pronounced by an Englishman, a Scottish, an Irishman, a Welsh, Canadian, Australian, American or South African' (Tunku Abdul Rahman Putra Al-Haj 2007:102).

Another important result of the Congress was the idea of founding the Language and Literary Council, adopting the Indonesia's Balai Pustaka. It aimed to advance the production of school textbooks for the primary to tertiary educational levels, to publish qualified literary works and advance research on both modern and classical Malay literature, in addition to promoting potentially talented writers. To initiate this institution, the Malayan government invited a number of Indonesian writers, including Sutan Takdir Alisjahbana (Ahmad Kamal Abdullah 2006:70).

It is noteworthy that two years before the Third Malay Language and Literary Congress was held, Malaya and Singapore sent a delegation of five representatives and fifteen observers under the leadership of Harun Aminurrasyid to attend the Language Congress held by the Indonesian Ministry of Education and Culture in Medan. (While in the Third Malay Congress in Johore, Indo-

25 Tunku Abdul Rahman Putra Al-Haj 2007:101-2. Interestingly, before coming to this point of view, he gave examples on how people in the northern and southern parts of the Peninsula used the same words but with different meanings. For instance, the common everyday word semalam which in the north and east of Malaya means 'last night', in the southern and central parts of Malaya means 'yesterday'. Similarly with the word bebal. In the north it means 'to show temper', but in the south it means 'stupid'. He then insisted that 'if even in our own country one word is used with dissimilar meanings in different parts of the country, then the dissimilarity in meanings would be more marked between Malaya and Indonesia'. See Tunku Abdul Rahman Putra Al-Haj 2007:99-100. 
nesia sent a group of scholars and writers which included Prof Dr Prijono, Prof Sutan Muhammad Zain, Prof Dr Poerbatjaraka, Dr Slamet Mulyono, Nur Sutan Iskandar, Mengatas, Amin Singgih and others (Li Chuan Siu 1975:34-5). At the Medan Congress, they learned that until 1954, Indonesia had published 40,000 books and brochures in Indonesian (Li Chuan Siu 1975:32) - something that impressed Tunku Abdul Rahman during his visit to Indonesia the following year, as cited above.

Obviously Malay nationalists, regardless of their ideological stands, still looked to Indonesia as the model for the cultural framework of the would-be independent Malaya. Unsurprisingly, what happened in Indonesia had its own resonance in Malaya. For example, the arts polemic between the members of LEKRA and the signatories of Surat Kepercayaan Gelanggang in the 1950s had its echo in Malaya, when the manifesto of ASAS 50, which paralleled LEKRA's, was challenged by the 'art for art's sake' manifesto launched by Hamzah, a former member of ASAS 50.

The polemic was indicative of the internal conflict within ASAS 50. Maman notes that most members of ASAS 50 were young writers who were sympathizers of radical Leftist political parties such as Parti Kebangsaan Melayu Malaya (PKMM) and Angkatan Pemuda Insyaf (API). They were enthusiastic about promoting and employing literature as an instrument for political struggle, as seen in the slogan of 'arts for society'. Asraf, one of the proponents of this manifesto, for example, was consistent with this concept. He observed that what Chairil Anwar and Idrus of Indonesia's 'Angkatan 45' had done was a good example for Malay writers for ways to reform the Malay language and literature. The best way for undertaking reform for the sake of the progress of the Malays was through literature being concerned with the life of the people (Maman S. Mahayana 2001:214-5), in the sense of the poor or the working class Malays as mentioned earlier.

To some members of ASAS 50 such as Hamzah and Rosmera, even though the Malay interpretation of 'the people' was not completely the same as the 'people' defined by LEKRA, such a literary manifesto tended towards communism - the ideology that had been suppressed by the British since the imposition of Emergency in 1948. Hamzah subsequently resigned from ASAS 50. Then he formed Angkatan Persuratan Melayu Baharu (PMB, New Malay Literary Association) in September 1954. Malay writers joining this association were Rosmera, M.S. Haliza, Abdul Salam Ayub, Aebe Muara, Amin Jaya, and Abdul Ghani Hamid. The central aim of this association was the promotion of a Malay literature referring to Islam (Maman S. Mahayana 2001:217). 
The UMNO's domination on the political and cultural stages and the internal conflict within ASAS 50 later caused the activities of this association to decline around the mid-1950s, despite its influence which was said to continue to reflect the Malay literary world in subsequent years. In addition, after the Federation of Malaya gained its independence in 1957, the centre of cultural activism moved (back) to Kuala Lumpur. Many Malay writers left Singapore for Kuala Lumpur. Now under the UMNO's brand of Malay nationalism, Malay writer-activists, regardless of their kind of nationalist aspiration, performed their work with a more nationalistic tone. It is questionable how they then perceived Indonesia. ${ }^{26}$ I will now discuss the 'exchange' of Malay and Indonesian writers before and after 'Confrontation', when Soekarno 'challenged' the existence of the Malaysian Federation.

THE 'EXCHANGE' OF MALAY AND INDONESIAN WRITER-ACTIVISTS BEFORE AND AFTER 'CONFRONTATION'

In a relatively brief period, the attainment of Malayan independence on 31 August 1957 was followed by the formation of the administratively untidy grouping of the Straits Settlements (Penang-Malacca-Singapore), the Federated and Unfederated Malay States and the diverse communities therein. They came together in a moment of nationhood. The new nation's leaders had close links with the old Malay aristocratic elites, or had been nurtured by the British for leadership roles. The arrangements they made between themselves were designed to fulfil the British demand for racial harmony and took the form of power sharing in the new parliament. However, as Hooker notes, true multiracialism was not achieved. None of the Alliance partners (UMNO and its alliances from the non-Malay-based-political parties) consistently represented the interests of their weaker constituents (Hooker 2003:207-8).

26 However, the newly independent Malayan Federation government continued to put Indonesia as its close ally. In early September 1957, a cultural mission toured Indonesia, including Yogyakarta where a Friendship Association between Malaya and Indonesia based on Islam was established. See the news section ('Berita kebudayaan') of Budaya 10 (Oktober 1957):444. While in the following year, the Federation of Malaya government sent seven Malay teachers to take an Indonesian language course in Indonesia for six months. They reportedly said that the Indonesian language was the language of science and culture; while the education ministers of Indonesia and the Federation of Malaya held a meeting in November 1958 assuring the cooperation of both countries in language, education and culture. See the news section of Budaya 11-12 (December 1958):476-7. 
Such a political configuration left a space for the Leftist ideas to survive. Partly this was because the mood of the times was antiimperialism. Even the 1960s threw up an idealistic and romantic generation of young Malay leftwing intellectuals, who impressed the public with their selflessness and dedication to a worldwide cause to bring about political justice, equality and a 'brave new world'. They comprised students, journalists, writers, lawyers and trade unionists (Cheah Boon-Kheng 2006:638).

Many of the Malay Leftists had been politically 'Indonesia oriented'. They still intensively observed and took inspiration from what happened in Indonesia to develop their own ideas and actions for what they believed to be the welfare of Malayan people. Such a stand must have put them in trouble, since independent Malaya was in search of its own 'national identity', refusing to be the shadow and echo of other nations, including Indonesia.

Ironically, especially as occurred with Samad Ismail, it was such a Malay 'Indonesia-oriented' Leftist nationalist who later played an important role in silently bridging non-formal diplomatic relations between Malaysia and Indonesia when the Indonesia's campaign to 'crush Malaysia' called 'Confrontation' broke out. ${ }^{27}$ The story began in early 1957, prior to the Malayan independence, when Yusof Ishak, Utusan Melayu's managing editor and editor-in-chief, moved the newspaper to Kuala Lumpur. Everyone assumed that Samad would be running the paper. Instead, Ishak assigned him to be Utusan's correspondent in Indonesia. According to Samad, Ishak told him 'I'm sorry, you can't go to Kuala Lumpur. If you go to Kuala Lumpur, Tunku will close down my paper.' So, says Samad, 'I went off quietly to Jakarta' (Rush n.d.).

In Indonesia, Samad was warmly welcomed by his old comrades. Adam Malik arranged for an office for him at Antara, the government news agency, and also a place to live. He introduced him to a number of leading political figures. This 'exile' gave him an opportunity to see independent Indonesia firsthand. He travelled extensively, and he was very disturbed and disillusioned to witness the poverty (Rush n.d.), indicating that he had some emotional attachment with Indonesia. ${ }^{28}$

27 In the remarks of R.S. Milne and Diane K. Mauzy (1986:155), the Indonesian objection was ideological rather than legal. President Soekarno saw the Malaysia proposal as a 'neocolonialist' scheme hatched by the British, whose troops were still in Malaya, thus proving that the country was not yet really independent.

28 In fact, his sympathy to Indonesia had been shown years earlier. In his position as the editor of Utusan Melayu in late 1940s, he laid down certain conditions. One of them was that Utusan Melayu should no longer describe Indonesian freedom fighters as pengganas or 'terrorists'; that Utusan must give full support to the Indonesian struggle for independence, and that it must give equal treatment to news about the left wing movement in the country. See Hamidah bte Haji Hassan 1987:41. 
In 1963, the already independent Federation of Malaya merged with the locally self-governing but not yet independent Singapore and two British colonies on Borneo (Sarawak and Sabah) to form Malaysia. This new and largely unanticipated entity altered the evolving political equation profoundly. Moreover, President Soekarno assailed the new Malaysian state as a neocolonial deception designed to extend British imperial power in the region indefinitely. Launching the so-called Confrontation, he vowed to destroy the new Malaysia (Rush n.d.).

Samad's close links to Tun Abdul Razak, the Tunku's deputy premier, placed him as the deputy premier's personal aide concerning the Indonesia problem. Working outside official channels, he contacted leaders of several non-aligned countries ${ }^{29}$ - Soekarno's assumed allies - and asked for their support for Malaysia. Through Adam Malik and other contacts in Indonesia, he also learned and passed along to worried Malaysian leaders, the news that Soekarno lacked support among significant elements of the Indonesian power structure for his assault on Malaysia. Indeed, when Soekarno was overthrown in 1965, Confrontation was immediately abandoned by Indonesia's new military rulers (Rush n.d.). As the 'hidden' bridge between the two countries had been laid down by Samad Ismail, the normalization of the diplomatic relation of the two countries was just a matter of time.

Samad's case shows a paradox. His Leftist nationalist stance and close links with Indonesia had put him in trouble in the context of the nation building project of the newly independent Malaya. However, in the time of crisis during the 'Confrontation' epoch, it was such a stance that made him play an important role in keeping contacts and building a silent diplomatic channel with Indonesia, so that the relations between the two countries was not trapped in total hostility.

On the other hand, as noted by Ahmad Kamal Abdullah, the presence of a number of (non-Leftist) Indonesian writers in Malaya in the early 1960s due to the dominance of LEKRA's politics of authorship and to the PKI's close link to Soekarno, maintained the cultural link of Malaya-Indonesia. These writers included Idrus, M. Balfas, Sutan Takdir Alisjahbana, and Mochtar Lubis. They associated well with Malay writers. Idrus made a dis-

29 Indonesia's hostility revealed how badly Malaya was in need of additional contacts and friends. Indonesia had used international conferences to urge its case against the formation of Malaysia and lobbied so successfully at the Afro-Asian Conference held in Tanganyika (later Tanzania) in 1963 that the delegation from Malaya-Singapore failed even to get seated (Milne and Mauzy 1986:155). 
cussion group consisting of Malay writers, in which he gave a series of talks on the philosophy of aesthetics. He even republished some of the works of Amir Hamzah such as Njanyi sunji (Soliloquy) and Buah rindu (The fruit of a longing) in Malaya (Ahmad Kamal Abdullah 2006:70), in addition to founding a publishing house, one of its publications being Jenaka magazine. He also published his own anthology of short stories, Dengan mata terbuka (With open eyes) (1961) and a novel entitled Hati nurani manusia (Human conscience) (1963). Both harshly criticized the corruption and the political patronage of business in Indonesia (Hill 2006:2-3). While M. Balfas, before moving to Australia to teach, actively assisted Keris Mas to run Dewan Pelajar, a special magazine for young children published by Dewan Bahasa dan Pustaka; and St. Takdir Alisjahbana was the head of the department of Malay Studies at the Malaya University (Ahmad Kamal Abdullah 2006:71-2).

Meanwhile, Mochtar Lubis used the opportunity of his 'exile' in Kuala Lumpur to publish his novel Sendja di Djakarta (Twilight in Jakarta) (1964). In fact he wrote the draft of this novel when he was under house detention in Jakarta in late 1950s. As it could not be published in Indonesia because it sharply criticized the corrupted Indonesian political life under the leadership of Soekarno, he sent it to London and Claire Holt translated it into English. It was first published in London in 1963 and in New York the following year. In the same year it was published in Kuala Lumpur in its Indonesian version, while its publication in Indonesia had to wait another six years (Hill 2006:3).

When diplomatic relations between Malaysia and Indonesia were normalized in 1966, the flow of Indonesian writers to Malaysia increased. Many Indonesian scholars played an important role in the formation of the first state university in Malaysia after independence, namely the Universiti Kebangsaan Malaysia (UKM) in early 1970s. Meanwhile many Malaysian students were sent to Indonesia for their tertiary education.

\section{CLOSING REMARKS}

Given the two-directional traffic of writer-activists between Malay(si) a and Indonesia at times of crisis, writers could play an important role in bridging the political tension of the two countries. Writers could represent a sort of alternative image of their home country. As noted above, the presence and activism of non-Leftist Indo- 
nesian writers such as Idrus and M. Balfas in Malaya could build an image that not all Indonesian cultural workers had a sense of hostility to Malaysia. While Samad's frequent visits to and stay in Indonesia could build an image among Indonesians that not all Malaysian cultural workers were supportive of the so-called British neo-colonialism project through the formation of Malaysia.

Such an exchange of 'ideologically marginalized' writers at times of crisis was only possible when the cultural traffic and links of the two countries had long historical precedent. As mentioned above, the history of the links between Malay[sian] and Indonesian modern literatures can be traced back to the mid-1920s. In the case of Malaya-Indonesia cultural links and traffic from 1920s to 1965, one might say that initially it was through literature that political influences were transmitted from Indonesia to Malaya, and finally that it was by writer-activists of the two countries that political tension between the two countries was partly resolved. In short, writeractivists could play a role as negotiators of the tension between the two siblings; or it was these writer-activists that made the two countries like siblings, as it was through literature that the idea of 'bangsa serumpun' was enlivened.

As stated at the outset, this chapter focuses on the Malay writers, particularly the Malay Left writers and their links and orientation to Indonesia. The picture revealed is complex enough, yet it is only one part of an even larger picture. This essay has not discussed the Chinese writers, who might have had their own links to both the Malays and Indonesians, which is another important aspect of cultural networking around the Malacca Strait. Nor has it focused on the networking of forms of culture other than literature at this time. These are subjects left for others to pursue.

REFERENCES

Ahmad Kamal Abdullah

2006 'Kesusastraan Indonesia-Malaysia mutakhir; Antara sensitiviti dan imaginasi'. Susastra 2-3:64-88.

Barnard, Timothy P. (ed.)

2004

Contesting Malayness; Malay identity across boundaries. Singapore: Singapore University Press.

2009

'Anak wayang and Singapore's entertaining past', in: Priscilla Chua (ed.), The past in the present; Histories in the making, pp. 126-42. Singapore: National Heritage Board. 
Cheah Boon-Kheng

2006 'The left-wing movement in Malaya, Singapore and Borneo in the 1960s; "an era of hope or devil's decade"?', Inter-Asia Cultural Studies 7-4:634-49.

Hamidah bte Haji Hassan

'A consummate actor', in: Cheah Boon Kheng (ed.), A. Samad Ismail; Journalism and politics, pp. 1-21. Kuala Lumpur: Singamal.

Hill, David T.

2006

'Politik identitas dalam budaya Indonesia/Melayu', Susastra 2-4:1-15.

Hooker, Virginia Matheson

2003

A short history of Malaysia; Linking east and west. St Leonards NSW: Allen \& Unwin.

Islam, Melayu, komunis

2005 Islam, Melayu, komunis; Wawancara dengan Abdullah C.D., Rashid Maidin, Abu Samah. Petaling Jaya: Strategic Information Research Development.

Jassin, H.B.

1983

Sastra Indonesia sebagai warga sastra dunia. Jakarta: Gramedia. Kahn, Joel S.

2006

Other Malays; Nationalism and cosmopolitanism in the modern Malay world. Singapore: Singapore University Press.

Kamaluddin Muhammad

1987

Kemala

n.d.

'A master of his craft', in: Cheah Boon Kheng (ed.), A. Samad Ismail; Journalism and politics, pp. 31-8. Kuala Lumpur: Singamal.

2008

'Hubungan sasterawan Malaysia - Indonesia'.

http: / / www.utusan.com.my/utusan/arcive.asp?y=2005\& $\mathrm{dt}=0918 \&$ pub=Utusan_Malaysia\&sec $=$ Sastera\&pg $=\mathrm{sa} \_01$. htm (accessed 10-9-2008).

'Kesusasteraan Melayu; Jalan ke danau berkilau (1)'. Paper presented at Pesta Puisi Nusantara 2008, Universitas Kediri, Jawa Timur, 1 July. http://jalansetapak.wordpress. com/2008/07/11/kesusastraan-melayu-jalan-ke-danauberkilau-1/ (accessed 20-12-2008).

Li Chuan Siu

An introduction to the promotion and development of modern Malay literature, 1942-1962. Yogyakarta: Kanisius. 
Maman S. Mahayana

2001

Akar Melayu; Sistem sastra dan konflik ideologi di Indonesia dan Malaysia. Magelang: IndonesiaTera.

Mauzy, Diane K.

2006 'From Malay nationalism to a Malaysian nation?' in: Lowell W. Barrington (ed.), After independence; Making and protecting the nation in post-colonial and post-communist states, pp. 45-70. Michigan: The University of Michigan Press.

Milne, R.S. and Diane K. Mauzy

1986 Malaysia; tradition, modernity, and Islam. Boulder/London: Westview Press.

Milner, A.

2002

The invention of politics in colonial Malaya. Cambridge: Cambridge University Press.

Mula Harahap

n.d. 'Rumah sakit korban lelaki dan pertukaran literatur Indonesia-Malaysia'.

http://mulaharahap.wordpress.com/2007/04/15/rumahsakit-korban-lelaki-dan-pertukaran-literatur-indonesiamalaysia/ (accessed 28-10-2008).

Mustapha Hussain

2005 Malay nationalism before UMNO; The memoirs of Mustapha Hussain. Kuala Lumpur: Utusan. [Translated by Insun Sony Mustapha.]

Rajakumar, M.

1987

'Malaysia's Jean-Paul Sartre', in: Cheah Boon Kheng (ed.), A. Samad Ismail; Journalism and politics, pp. 39-42. Kuala Lumpur: Singamal.

Roff, William R.

1967 The origins of Malay nationalism. New Haven: Yale University Press. Rush, James R.

n.d. 'Pak Samad; A biographical sketch'.

http:/ / dinmerican.wordpress.com/2008/09/05/paksamada-biographical-sketch/ (accessed 16-10-2008).

Rustam A. Sani

n.d.

'Usman Awang, penyair terbesar negara'. http://detik. daily.tripod.com/disa/7dis_3.htm (accessed 30-10-2008).

Said Zahari

2007

The long nightmare; My 17 years as a political prisoner. Kuala Lumpur: Utusan. 
Shafwan Hadi Umry

2008 'Pesona Amir Hamzah di Malaysia', Republika (24 February). Soh, Byung-kuk

2005 'Ideals without heat; Indonesia Raya and the struggle for independence in Malaya, 1920-1948', The Asian Scholar 1. http://www.asianscholarship.org/asf/ejourn/toc.html (accessed 20-3-2007).

Tunku Abdul Rahman Putra A-Haj

2007 Malaysia; The road to independence. 2nd printing. Subang Jaya: Pelanduk Publications. 